DOI https://doi.org/10.30525/978-9934-588-90-7-28

\title{
ЕКОЛОГІЧНИЙ ТЕРМІН ЯК БАЗОВИЙ ЕЛЕМЕНТ ФАХОВОЇ КОМУНІКАЦЇ̈
}

\author{
Боднар О. М. \\ кандидат філологічних наук, \\ доиент кафедри німецької філології \\ Ужггородський начіональний університет \\ м. Ужггород, Україна
}

Формування науки екології стимулювало і розвиток відповідної фахової мови, покликаної обслуговувати цю професійну галузь знань.

Екологічний термін як одиниця галузевої терміносистеми має такі основні ознаки: номінативність; наявність визначення (дефініції); залежність від контексту, в першу чергу, коли мова йде про біологічні терміни; чітко визначене місце в екологічній терміносистемі; тенденцію до моносемії в межах терміносистеми екологічної галузі; точність позначення екологічного поняття; стилістичну нейтральність; відсутність експресивних значень; системні відношення та зв'язки у межах екологічної терміносистеми, суміжних з нею галузевих терміносистем та загальновживаної лексики; мотивованість, що реалізується у трьох типах, які відповідають трьом основним способам термінологічного словотворення (морфологічному, синтаксичному і семантичному) [3].

Терміносистема екології містить поняттєві підсистеми таких галузей знань, як біологія, геологія, гідрологія та агроекологія, архітектурна екологія, інженерна екологія [1, с. 135].

Поширення сфери природоохоронної діяльності, виникнення нових галузей екології на стику наук зумовлюють активне творення екологічної термінолексики з залученням термінів із суміжних сфер. Таким чином, термінологія фахової мови екології поповнюється новими термінами, удосконалює поняттєвий апарат відповідної науки.

Так, зокрема екологія як наука біологічного циклу послуговується термінами власне біології:

die Kontamination - контамінація (від лат. contaminare - забруднювати) - ,забруднення предметів, приміщень і навколишнього середовища отруйними хімічними і радіо-активними речовинами, вірусами" [2, c. 236];

die Aggregation - агрегащія (від лат. aggregare - нагромаджувати) „утворення більш-менш стійких, різних за величиною і біологічним значенням груп організмів у межах ареалів їх популяцій” [2, с. 15]; 
das Biom, das Bios, die Biota - бioma (від гр. biote - життя) - „складний взаємоповязаний комплекс живих істот (рослини, тварини, мікроорганізми) в межах екосистеми" [2, с. 59] тощо.

До складу терміносистеми фахової мови екології можуть входити терміни з таких галузей:

- генетики: das Gen;

- мови засобів масової інформації: die Glasnost, die Publizität;

- загальнонаукові: der Faktor, das Gesetz, der Index, der Koeffizient, die Methode, die Rate, das System, die Zahl, das Verfahren тощо.

Якщо зазначені терміни входять до складу терміносполучень та/або складних термінів на позначення понять та явищ екології, у такому разі вони стають складовими екологічної терміносистеми:

das Bevölkerungsgesetz (закон народонаселення Мальтуса) [5, с. 185];

das Minimumgesetz, das Gesetz vom Faktor im Minimum (закон мінімуму Лібіха) [5, c. 246];

das Wirkungsgesetz der Wachstumsfaktoren (закон сукупної дії природних факторів) [5, с. 598];

der Saprobie(n)Index (індекс/коефіцієнт сапробності) [5, с. 499];

der Ausnutzungskoeffizient (коефіцієнт використання) [5, с. 176];

die Abwasserbelastungsrate (ступінь забрудненості стічними водами) [5, с. 133];

die Abfallbeseitigungsmethode (метод знешкодження відходів) [5, c. 166];

die Wassergefährdungszahl (показник/коефіцієнт шкідливості для вод) [5, с. 408];

die Adsorbtionszahl (коефіцієнт абсорбції) [5, с. 62];

der Akkumulationsfaktor, der Anreicherungsfaktor, der Bioakkumulationsfaktor, der Biokonzentrationsfaktor (коефіцієнт біоакумуляціï) [5, с. 241];

der Emissionsfaktor (коефіцієнт викиду забруднюючих речовин) [5, с. 375];

das Abwasserbehandlungssystem (система/технологія очищення стічних вод) [5, с. 189];

das Abwasserbehandlungsverfahren (метод очищення стічних вод) [5, с. 188];

das Sauerstoffbegasungsverfahren (метод аерації киснем) [5, с. 539].

Оскільки терміносистеми різних галузей не $\epsilon$ ізольованими, а перебувають у взаємозв'язку, вони містять уніфіковані щодо норм сучасної мови терміни на міжгалузевому рівні $[4$, с. 148]. Слід вказати на інтегративний характер понять i категорій екології та інших природничих наук:

біологія: das Siedelgebiet (ареал видів) [5, с. 567]; 
фізика: das Geräuschspektrum (акустичний спектр) [5, с. 234];

метеорологія: die Jahresniederschläge (річна кількість опадів) [5, с. 345]; географія: die Wirtschaftslandschaft (техногенний ландшафт) [5, с. 728];

океанологія: die Verschmutzung der Meere (забруднення світового океану) [5, с. 734];

хімія: die Schadstoffgrenze (порогова маса небезпечних речовин) [5, с. 672];

радіологія: die Interventionsschwelle (поріг втручання) [5, с. 385];

медицина: die Schmerzschwelle (поріг больового відчуття) [5, с. 675];

правознавство: die Gifffreisetzung (викид токсичних речовин у навколишнє середовище (вид екологічного злочину) [5, c. 231].

Межа між терміносистемами екології та інших природничих наук $\epsilon$ нечіткою, розмитою, оскільки спостерігається міграція термінів.

\title{
Література:
}

1. Бондар О., Козловська Л. Семантико-граматичні типи терміносполук у галузі екології. Українська термінологія і сучасність: зб. наук. праць. К., 2003. Вип. V. С. 134-139.

2. Мусієнко М. М., Серебряков В. В., Брайон О. В. Екологія. Охорона природи: словник-довідник. К. : Знання, 2002. 550 с.

3. Овсейчик С. В. Формування української екологічної термінології: дис. ... канд. філол наук: 10.02.01. К., 2006. 199 с.

4. Панько Т. І., Кочан І. М., Мацюк Г. П. Українське термінознавство. Львів: Світ, 1994. 216 с.

5. Новиков Ю. Н. Немецко-русско-немецкий словарь по экологии и защите окружающей среды. М. : ЭТС Polyglossum, 2004. 980 c.

DOI https://doi.org/10.30525/978-9934-588-90-7-29

\section{СПЕЦИФІКА РЕЛІГІЙНОГО ДИСКУРСУ}

\author{
Бондаренко К. А. \\ кандидат філологічних наук,
}

доцент кафедри теоретичної та прикладної фонетики англійської мови

Одеський начіональний університет імені I. I. Мечникова

м. Одеса, Україна

Наукове вивчення релігійного дискурсу, активізоване останнім часом на пострадянському просторі, становить не лише особливий інтерес, а й певні труднощі. Будучи за формальними ознаками інституційним 108 